\title{
Glass Frit Dissolution Influenced by Material Composition and the Water Content in Iodide/Triiodide Electrolyte of Dye-Sensitized Solar Cells
}

\author{
Katrine Flarup Jensen, ${ }^{1,2}$ Md. Mahbubur Rahman, ${ }^{3}$ Welmoed Veurman, ${ }^{1}$ Henning Brandt, ${ }^{1}$ \\ Chan Im, ${ }^{2}$ Jürgen Wilde, ${ }^{4}$ Andreas Hinsch, ${ }^{1}$ and Jae-Joon Lee ${ }^{2,3,5}$ \\ ${ }^{1}$ Fraunhofer Institute for Solar Energy Systems (ISE), HeidenhofstraBe 2, 79110 Freiburg, Germany \\ ${ }^{2}$ Konkuk University-Fraunhofer Next Generation Solar Cell Research Center (KFnSC), 120 Neungdong-ro, Gwangjin-gu, Seoul 143-701, \\ Republic of Korea \\ ${ }^{3}$ Department of Advanced Technology Fusion, Konkuk University, 120 Neungdong-ro, Gwangjin-gu, Seoul 143-701, Republic of Korea \\ ${ }^{4}$ Department of Microsystems Engineering-IMTEK, University of Freiburg, Georges-Köhler-Allee 103, 79110 Freiburg, Germany \\ ${ }^{5}$ Nanotechnology Research Center and Department of Applied Chemistry, Konkuk University, 268 Chungwondaero, Chungju 380-701, \\ Republic of Korea
}

Correspondence should be addressed to Andreas Hinsch; andreas.hinsch@ise.fraunhofer.de and Jae-Joon Lee; jjlee@kku.ac.kr

Received 6 February 2013; Revised 11 June 2013; Accepted 11 June 2013

Academic Editor: Theodoros Dimopoulos

Copyright (C) 2013 Katrine Flarup Jensen et al. This is an open access article distributed under the Creative Commons Attribution License, which permits unrestricted use, distribution, and reproduction in any medium, provided the original work is properly cited.

\begin{abstract}
To ensure long-term stable dye-sensitized solar cells (DSCs) and modules, a hermetic sealing is required. This research investigates the chemical stability of $\mathrm{I}^{-} / \mathrm{I}_{3}{ }^{-}$redox electrolyte and four different glass frits (GFs). Sintered GF layers were openly exposed to nonaqueous redox electrolyte and redox electrolyte with 1,5 , and $10 \mathrm{wt} \% \mathrm{H}_{2} \mathrm{O}$ in thin, encapsulated cells. The change in $\mathrm{I}_{3}{ }^{-}$ absorbance was assigned to a reaction between the GF and $\mathrm{I}^{-} / \mathrm{I}_{3}{ }^{-}$electrolyte and was used to evaluate the chemical stability of the different GFs. The $\mathrm{I}_{3}{ }^{-}$absorbance change was monitored over 100 days. Two out of the four GFs were unstable when $\mathrm{H}_{2} \mathrm{O}$ was added to the redox electrolyte. The $\mathrm{H}_{2} \mathrm{O}$ caused metal ion leaching which was determined from EDX analysis of the inorganic remains of electrolyte samples. A GF based on $\mathrm{Bi}_{2} \mathrm{O}_{3}-\mathrm{SiO}_{2}-\mathrm{B}_{2} \mathrm{O}_{3}$ with low bond strength leached bismuth into electrolyte and formed the $\mathrm{BiI}_{4}{ }^{-}$complex. A $\mathrm{ZnO}-\mathrm{SiO}_{2}-\mathrm{Al}_{2} \mathrm{O}_{3}$-based $\mathrm{GF}$ also became unstable when $\mathrm{H}_{2} \mathrm{O}$ was added to the redox electrolyte. Leaching of zinc ions due to exchange with $\mathrm{H}^{+}$resulted in the formation of a zinc-iodine compound which caused $\mathrm{I}_{3}{ }^{-}$depletion. By applying the test design to different types of GFs, the material suitability in the DSC working environment was investigated.
\end{abstract}

\section{Introduction}

The dye-sensitized solar cell (DSC) is a photoelectrochemical cell which imitates nature's photosynthesis [1]. In its classical configuration, see Figure 1, the cell consists of 2 glass substrates coated with transparent conductive oxide (TCO) (usually $\mathrm{SnO}_{2}: \mathrm{F}$ on soda-lime glass) on which the electrodes are deposited. The photoelectrode consists of a mesoporous layer of semiconductive $\mathrm{TiO}_{2}$ with a monolayer of chemically adsorbed dye. The transparent counter electrode is coated with a very thin catalytic layer of platinum. A liquid redox electrolyte containing the redox couple iodide/triiodide
$\left(\mathrm{I}^{-} / \mathrm{I}_{3}^{-}\right)$is encapsulated between the two electrodes by a sealant agent, resulting in a plate distance of $20-50 \mu \mathrm{m}$. When light strikes the solar cell, the photon is absorbed by the dye. The excited dye injects an electron into the $\mathrm{TiO}_{2}$ conduction band which diffuses through the $\mathrm{TiO}_{2}$ network. The electron enters the external circuit through the TCO and is transferred to the counter electrode. The photo-oxidized dye injects an electronic hole into the electrolyte which, in the form of $\mathrm{I}_{3}{ }^{-}$ diffuses to the counter electrode. At the counter electrode, $\mathrm{I}_{3}{ }^{-}$ is reduced back to $\mathrm{I}^{-}$.

In order to make the DSC attractive to the building industry, long-term stable, large modules on single substrates 
have to be realized. A thermally and chemically stable sealant is inevitably required to avoid degradation of the DSC. The degradation of the DSC can be caused either by intrinsic instability of the cell components or mechanically by electrolyte leakage or intrusion of $\mathrm{H}_{2} \mathrm{O}$ or $\mathrm{O}_{2}$ from the outside environment $[2,3]$.

To achieve long-term stable DSCs, $\mathrm{H}_{2} \mathrm{O}$ in the electrolyte should be prevented. Although $\mathrm{H}_{2} \mathrm{O}$ in electrolyte can create an initial increase in photovoltage [4], faster device degradation has been reported [4]. This is assumed to be due to loss of iodine when $\mathrm{H}_{2} \mathrm{O}$ is present in the electrolyte [4] as well as dye detachment from the $\mathrm{TiO}_{2}[5]$.

Many materials have been explored as sealant material such as thermoplastic hotmelt foils like Surlyn 1702 (DuPont) and Bynel 4702 (Dupont), UV curable glues, and glass frit (GF) $[6,7]$. GF is used as sealing material at Fraunhofer ISE. GF is believed to be a strong candidate as sealant material in glass-based DSC modules as it possesses the same properties as the substrates [8-10], is nonpermeable, and is UV- and temperature stable in the temperature range which can occur in hot climates. But it is not trivial to find a suited $\mathrm{Pb}$-free [11] GF with low melting temperature that is chemically stable against the oxidative redox electrolyte. It has previously been reported that GF was seen to leach elements into electrolyte $[12,13]$, which caused depletion of $\mathrm{I}_{3}{ }^{-}$and electrochemical degradation of the DSC.

The present work investigates the chemical stability of four low-temperature melting GFs in $\mathrm{I}^{-} / \mathrm{I}_{3}{ }^{-}$redox electrolyte. The stability of the GFs were investigated individually in nonaqueous $\mathrm{I}^{-} / \mathrm{I}_{3}{ }^{-}$redox electrolyte and in $\mathrm{I}^{-} / \mathrm{I}_{3}{ }^{-}$redox electrolyte containing 1,5 , and $10 \mathrm{wt} \% \mathrm{H}_{2} \mathrm{O}$. The design of experiments will be helpful to evaluate a GF for its compatibility and stability in the DSC environment.

\section{Materials and Methods}

2.1. Materials. The redox electrolyte contained $0.1 \mathrm{M}$ iodine (Sigma-Aldrich), $0.1 \mathrm{M}$ guanidine thiocyanate (SigmaAldrich), and $0.50 \mathrm{M}$ n-butyl-1H benzimidazole (NBB) (Merck, Germany) dissolved in 1-methyl-3-propylimidazolium iodide (PMIM-I) (Merck, Germany) with $11 \mathrm{wt} \%$ acetonitrile (Sigma-Aldrich). Demineralized water was used throughout the experiments to create redox electrolytes with 1,5 , and $10 \mathrm{wt} \% \mathrm{H}_{2} \mathrm{O}$. Due to the great excess of $\mathrm{I}^{-}$, all $\mathrm{I}_{2}$ is expected to have reacted to $\mathrm{I}_{3}{ }^{-}$by the following reaction,

$$
\mathrm{I}^{-}+\mathrm{I}_{2} \longrightarrow \mathrm{I}_{3}^{-}
$$

The diffusion coefficient of $\mathrm{I}_{3}{ }^{-}, \mathrm{D}\left[\mathrm{I}_{3}{ }^{-}\right]$was experimentally determined by cyclic voltammetry as described elsewhere [13]. $\mathrm{D}\left[\mathrm{I}_{3}{ }^{-}\right]$in the electrolyte with $10 \mathrm{wt} \% \mathrm{H}_{2} \mathrm{O}$ was determined to be $1.5 \cdot 10^{-6} \mathrm{~cm}^{2} / \mathrm{s}$ at $25^{\circ} \mathrm{C}$.

Soda-lime glass with a transparent conductive oxide $\left(\mathrm{SnO}_{2}: \mathrm{F}, 8 \Omega / \square\right)$ was purchased from Pilkington.

The GFs were used as received from the manufacturers, and the main compositional elements of the GFs are given in Table 1 . The melting temperature, $T_{m}$, was experimentally determined by heating the GF paste to various temperatures

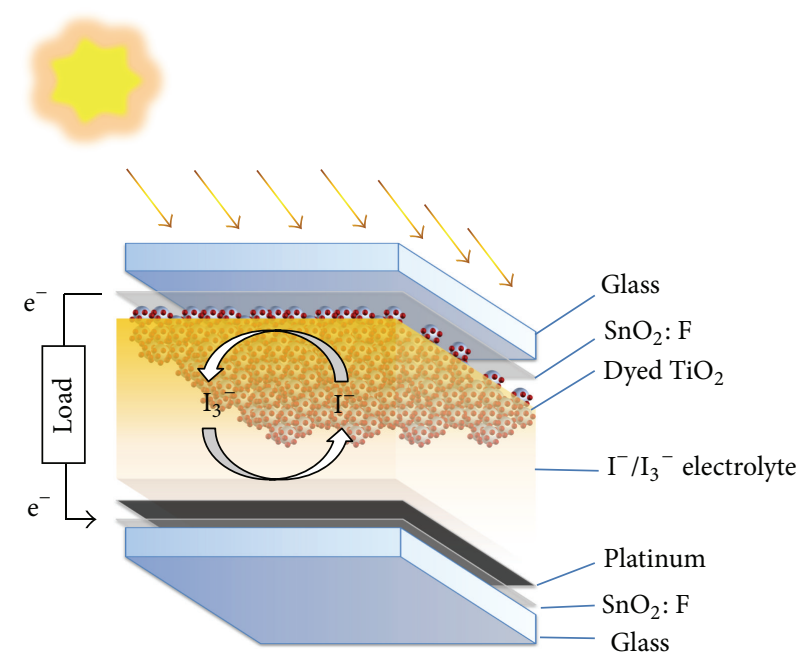

FIGURE 1: Working principle and device structure of a dye-sensitized solar cell (DSC). An organic electrolyte with the redox couple $\mathrm{I}^{-} / \mathrm{I}_{3}{ }^{-}$ transports the positive charge between the mesoscopic photoelectrode and the counter electrode.

TABLE 1: Main composition of glass frits for sealing.

\begin{tabular}{llc}
\hline & Composition & $T_{m}\left({ }^{\circ} \mathrm{C}\right)$ \\
\hline GF1 & $\mathrm{Bi}_{2} \mathrm{O}_{3}-\mathrm{SiO}_{2}-\mathrm{B}_{2} \mathrm{O}_{3}$ & 470 \\
GF2 & $\mathrm{Bi}_{2} \mathrm{O}_{3}-\mathrm{SiO}_{2}-\mathrm{B}_{2} \mathrm{O}_{3}$ & 400 \\
GF3 & $\mathrm{ZnO}_{-} \mathrm{SiO}_{2}-\mathrm{Al}_{2} \mathrm{O}_{3}$ & $500-520$ \\
GF4 & $\mathrm{SiO}_{2}-\mathrm{ZnO}-\mathrm{Al}_{2} \mathrm{O}_{3}$ & 530 \\
\hline
\end{tabular}

$T_{m}$ : temperature where glass powder initiates to melt.

and by investigating the particles by SEM. The onset of melting was determined as $T_{m}$.

2.2. The Test Cell. In the working DSC, the sealing material will only be exposed to the electrolyte at the typically $20-$ $50 \mu \mathrm{m}$ high cell edges. But with the aim to perform accelerated testing, we created a system with a larger (approx. 30 times) openly exposed GF area. The total cell area was $5 \mathrm{~cm} \times$ $0.6 \mathrm{~cm}$. An area of $2 \mathrm{~cm} \times 0.4 \mathrm{~cm}$ GF was doctor bladed on one TCO glass (Pilkington TEC-8) and dried in a convection furnace at $150^{\circ} \mathrm{C}$ for about $10 \mathrm{~min}$. The samples were sintered with the manufacturer's recommended sintering profile. An intermediate step in the heating curve assured that the organic binder was burnt out of the paste, before melting of the glass particles $[2,9]$. The peak sintering temperature $T_{\max }$ was approximately $50^{\circ} \mathrm{C}$ higher than $T_{m}$ (given in Table 1). The GF layer had a height of $12 \mu \mathrm{m}$ after sintering. This TCO glass was sealed with another TCO glass by a Surlyn gasket $(45 \mu \mathrm{m})$ as described in [7], creating encapsulated cells with a plate distance of $20 \mu \mathrm{m}$; see Figure 2. The widely used Surlyn is chemically stable, but it has a softening point of $65^{\circ} \mathrm{C}$, so it is not suitable for tests exceeding $60^{\circ} \mathrm{C}$ [7]. Surlyn was used as encapsulation to isolate the effect of GF on the confined area inside the cell and was suitable as the storage and exposure temperatures of the cells were mild (room temperature). The cells were filled with electrolyte, and the filling holes were 

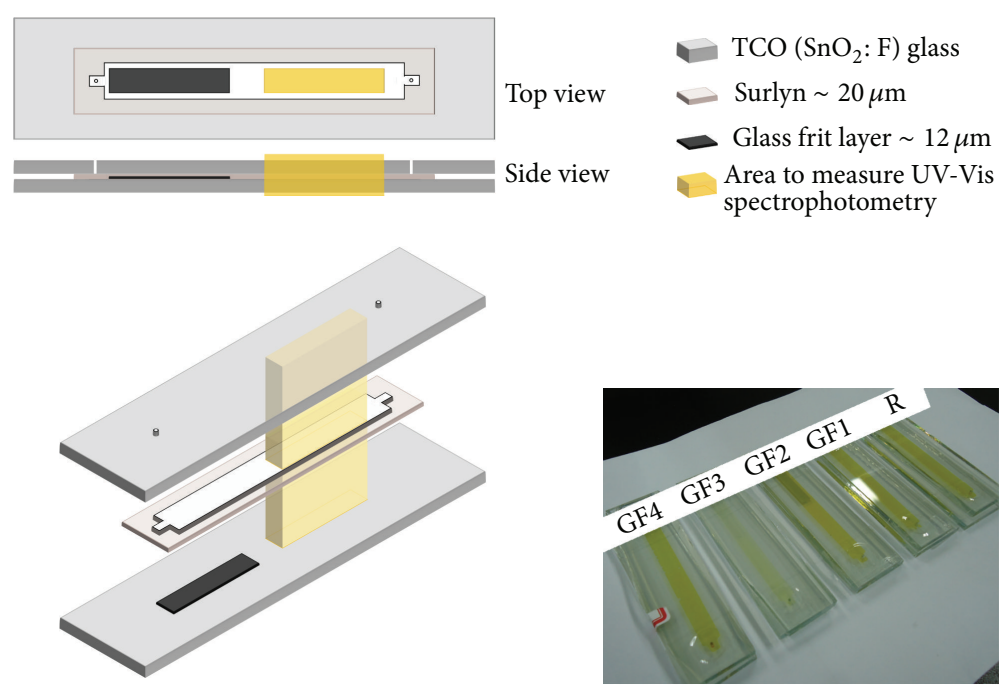

FIGURE 2: Cell design for investigating the accelerated influence of GF and $\mathrm{H}_{2} \mathrm{O}$ in the DSC electrolyte. Restricted area with a thin layer of GF and an area for absorbance measurements through the cell. The photo displays the test cells with 10 wt $\% \mathrm{H}_{2} \mathrm{O}$ in the redox electrolyte after 100 days. $R$ indicates the reference cell (no GF).

sealed with Surlyn and a thin slide glass. The reference cells did not contain a GF layer.

2.3. SEM and EDX Sample Preparation. After 100 days, the electrolyte samples were extracted from the cells and placed on a TCO $\left(\mathrm{SnO}_{2}: \mathrm{F}\right)$ glass, which is classified as chemically inert and thermally stable up to $600^{\circ} \mathrm{C}$ [14]. Solvents were evaporated, and the organic iodide salt was burnt out at $350^{\circ} \mathrm{C}$, so precipitated residues from the electrolyte could be examined with SEM and EDX. The samples were sputtered with Au to enhance the conductivity.

2.4. Instrumentation. UV-visible measurements were carried out with a spectrophotometer (Scinco UV-Vis spectrophotometer, Neosys 2000) with a detection limitation for transmittance lower than $10^{-2}$. Absorbance of the electrolyte inside the cell was measured from $350 \mathrm{~nm}$ to $500 \mathrm{~nm}$. The baseline was taken with a test cell containing $\mathrm{H}_{2} \mathrm{O}$.

A scanning electron microscope, SEM, and energy dispersive X-ray analysis, EDX, (FESEM JSM 6700F) were used to investigate the morphology and analyze the leached GF elements.

The GF layer thickness was determined with a Dektak profilometer.

\section{Results}

3.1. Absorbance Spectrum of $\mathrm{I}_{3}{ }^{-}$. The absorbance spectrum of $\mathrm{I}_{3}{ }^{-}$in acetonitrile has specific absorbance peaks at around $290 \mathrm{~nm}$ and $360 \mathrm{~nm}$ [15]. $\mathrm{I}_{3}{ }^{-}$absorbs until approximately $500 \mathrm{~nm}$. Calibration measurements with known $\mathrm{I}_{3}{ }^{-}$concentration in redox electrolyte showed a slight red-shift of the absorbance peak to $366 \mathrm{~nm}$, Figure 3(a), due to the difference in polarity of the ionic liquid PMIM-I compared with acetonitrile [16]. A good linear dependence between absorbance and $\mathrm{I}_{3}{ }^{-}$concentration according to Beer-Lambert's law [17] was observed at $366 \mathrm{~nm}$ as well as $430 \mathrm{~nm}$, Figure 3(b). The linearity at $430 \mathrm{~nm}$ will be used to correlate the glass frit interaction with $\mathrm{I}_{3}^{-}$loss since the test cells showed absorbance saturation at $366 \mathrm{~nm}$.

3.2. Detection of $\mathrm{I}_{3}{ }^{-}$Change in Electrolyte by UV-Vis Spectrophotometry. Absorbance measurements on the test cells were performed during 100 days. The absorbance spectra of the cells with redox electrolyte were saturated for most samples. This was due to the high triiodide concentration in the electrolyte. Therefore, the absorbance value at $366 \mathrm{~nm}$ could not be determined.

The absorbance spectra for the reference cell (no GF) and the test cells with GF1-GF4 containing redox electrolyte with 5 and 10 wt $\% \mathrm{H}_{2} \mathrm{O}$ are shown in Figures 4(a)-4(e). Only selected representative data are shown. The largest change in absorbance over time was seen for the cells containing GF2 and GF3 when $\mathrm{H}_{2} \mathrm{O}$ was added to electrolyte.

Figure 4(a) displays the initial absorbance spectra of the reference cell (no GF) with water-containing electrolyte initially and after 99 days. No changes in the spectra are seen. This was also the case for the test cells with GF1, Figure 4(b), and GF4, Figure 4(e), which showed constant absorbance spectra over time. Therefore, a long-term reaction between $\mathrm{H}_{2} \mathrm{O}$ and $\mathrm{I}_{3}{ }^{-}$under the mild storage conditions (dark, room temperature) can be excluded. Figures 4(c) and 4(d) clearly show that the $\mathrm{I}_{3}{ }^{-}$concentration decreases over time in the test cells with GF2 and GF3. The reason for $\mathrm{I}_{3}{ }^{-}$depletion can thus be assigned to the GF material and the addition of $\mathrm{H}_{2} \mathrm{O}$ in the system.

The absorbance spectra for the cell with GF2 changed over time and displayed a new absorbance peak at $475 \mathrm{~nm}$, Figure 4(c). This will be further discussed in Section 4.1.

For the cells with GF3 and $\mathrm{H}_{2} \mathrm{O}$-containing electrolyte, a continuous decrease of the absorbance was seen. After 71 days, the characteristic absorbance peak of $\mathrm{I}_{3}{ }^{-}$at $366 \mathrm{~nm}$ 


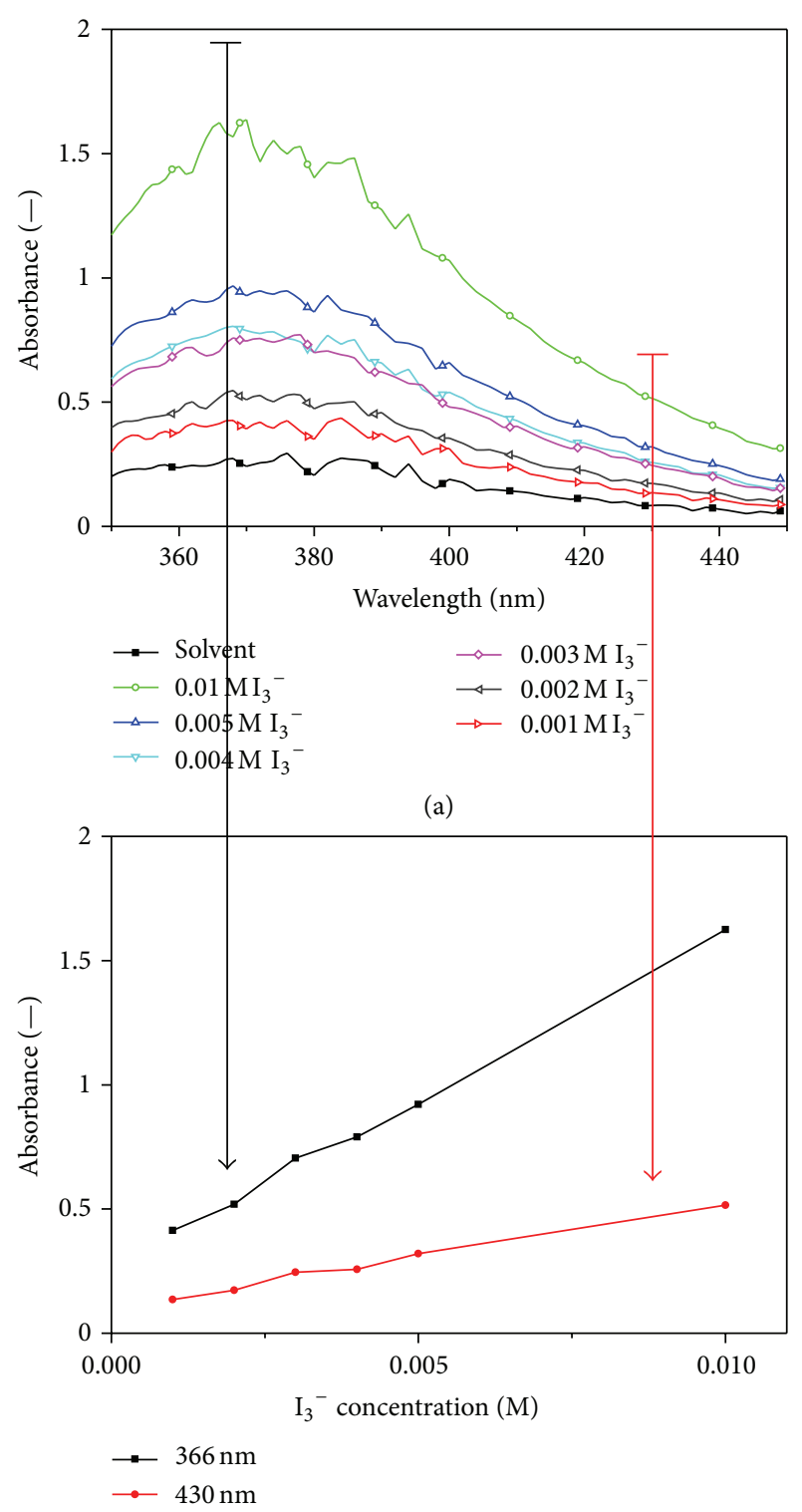

(b)

FIgURe 3: (a) Absorbance spectra of $\mathrm{I}_{3}{ }^{-}$in PMIM-I at various concentrations. $45 \mu \mathrm{m}$ light path length, $\mathrm{H}_{2} \mathrm{O}$ as baseline. The absorbance peak of $\mathrm{I}_{3}{ }^{-}$is seen at $366 \mathrm{~nm}$. (b) Linear dependence of $\mathrm{I}_{3}{ }^{-}$concentration with absorbance at, respectively, $366 \mathrm{~nm}$ and $430 \mathrm{~nm}$. The linearity at $430 \mathrm{~nm}$ is important since the absorbance spectra for the test cells are saturated at $366 \mathrm{~nm}$. Therefore, the decrease in absorbance at $430 \mathrm{~nm}$ for the test cells is correlated with the loss of $\mathrm{I}_{3}^{-}$.

became visible due to the significant decrease in $\mathrm{I}_{3}{ }^{-}$concentration, Figure 4(d).

The linearity between $\mathrm{I}_{3}{ }^{-}$concentration and absorbance at $430 \mathrm{~nm}$ was shown in Figure 3(b). Due to measurement saturation at $366 \mathrm{~nm}$, the absorbance at $430 \mathrm{~nm}$ as a function of time for the cells with GF2 and GF3 is shown in Figure 5.

As it can be seen from Figure 5(a), a decrease in $\mathrm{I}_{3}{ }^{-}$ absorbance for the GF2-containing cell is already visible when $1 \mathrm{wt} \% \mathrm{H}_{2} \mathrm{O}$ is added to the redox electrolyte. The absorbance decrease, when respectively $5 \mathrm{wt} \%$ and $10 \mathrm{wt} \%$
$\mathrm{H}_{2} \mathrm{O}$ are added to electrolyte, follows a similar decay trend and becomes linear after approximately 70 days.

In Figure 5(b), the results for the cell with GF3 are shown. A decrease in absorbance is seen when respectively 5 and $10 \mathrm{wt} \% \mathrm{H}_{2} \mathrm{O}$ are added to the electrolyte, with a less strong decrease for the cell with $5 \mathrm{wt} \% \mathrm{H}_{2} \mathrm{O}$ in the electrolyte. The absorbance decrease for the cell with $10 \mathrm{wt} \% \mathrm{H}_{2} \mathrm{O}$ becomes linear after 70 days, as it was also observed for the cells with GF2.

3.3. Diffusion Limitation of $\mathrm{I}_{3}{ }^{-}$in the Cell Design. The decrease in $\mathrm{I}_{3}{ }^{-}$content of the cell with GF3 and aqueous electrolyte was clearly visible, as the electrolyte bleached rapidly in the area of the GF layer. The diffusion of $\mathrm{I}_{3}{ }^{-}$from the uncoated area to the area with GF, therefore, seems to be of importance for the depletion time of $\mathrm{I}_{3}{ }^{-}$.

The largest $\mathrm{I}_{3}{ }^{-}$concentration gradient will be from the end of the GF area to the end of the noncoated area $(\sim 3 \mathrm{~cm})$. The relation between $\mathrm{I}_{3}{ }^{-}$diffusion coefficient $\mathrm{D}\left[\mathrm{I}_{3}{ }^{-}\right]$determined at room temperature, diffusion length $L$, and diffusion time $\tau\left(\tau=L^{2} / \mathrm{D}\left[\mathrm{I}_{3}^{-}\right]\right)$gives a diffusion time $\tau \sim 70$ days, for $\mathrm{D}\left[\mathrm{I}_{3}{ }^{-}\right]=1.5 \cdot 10^{-6} \mathrm{~cm}^{2} / \mathrm{s}$ and $L=3 \mathrm{~cm}$. This is in good correspondence with the initiation of the observed linear decay in absorbance as seen in Figure 5.

3.4. EDX Investigation of Leached GF Elements in Redox Electrolyte with $10 \mathrm{wt} \% \mathrm{H}_{2} \mathrm{O}$. After 100 days, the electrolyte was extracted from the cells, placed on a TCO glass, and heat treated. The leached GF elements could be determined by EDX. As the TCO consists of $\mathrm{SnO}_{2}: \mathrm{F}, \mathrm{Sn}$ and $\mathrm{O}$ elements were detected in all EDX spectra.

The EDX spectrum of the precipitate from the reference cell with nonaqueous redox electrolyte is displayed in Figure 6(a). The EDX analysis was performed on the area shown in the inserted SEM image. The detected Sn, O, and $\mathrm{F}$ originated from the TCO substrate, $\mathrm{C}$ and $\mathrm{Na}$ from trace amounts in the electrolyte [18], and $\mathrm{Au}$ from the $\mathrm{Au}$ sputtering for better conductivity. It should be noted that no iodine was detected, so the heat treatment had successfully burnt out the iodine from the redox electrolyte.

The EDX spectra from the remains of the aqueous electrolyte $\left(10 \mathrm{wt} \% \mathrm{H}_{2} \mathrm{O}\right)$ in contact with GF2 and GF3 are shown in the Figures 6(b) and 6(c). The insets show the SEM images of the precipitate. The spectra were obtained by performing spot analysis on the precipitates.

The precipitate from the redox electrolyte with $10 \mathrm{wt} \%$ $\mathrm{H}_{2} \mathrm{O}$ extracted from the test cell with GF2 contained bismuth and iodide. For the test cell with GF3, zinc and iodide were detected as the precipitate. In order to ensure that zinc was detected, the acceleration voltage was increased to $20 \mathrm{keV}$ for the sample with GF3. This caused the electron beam to go through the precipitate and the TCO and reach the soda-lime substrate. Hence, silicon was further detected.

The detected metals originated from the GF, and the iodine was from the electrolyte. Since iodine was burnt out during the heating of electrolyte, the detected bismuth and iodine for the GF2 sample and the detected zinc and iodine for the GF3 sample were bound in a thermally stable form. 


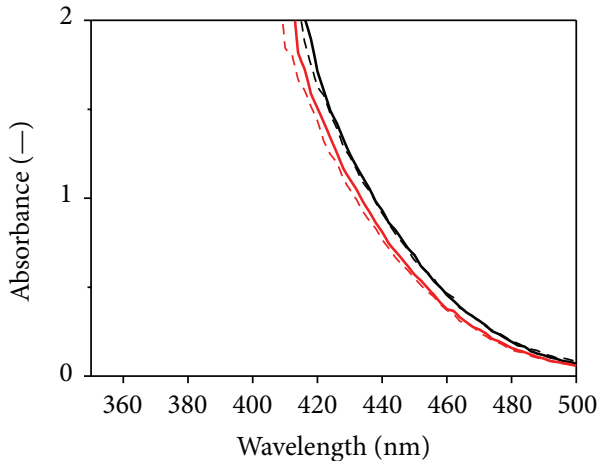

- Reference $5 \mathrm{wt} \% \mathrm{H}_{2} \mathrm{O}$ - - - Day $99,5 \mathrm{wt} \% \mathrm{H}_{2} \mathrm{O}$ - Reference $10 \mathrm{wt} \% \mathrm{H}_{2} \mathrm{O}$ - - - Day 99, $10 \mathrm{wt} \% \mathrm{H}_{2} \mathrm{O}$

(a) Reference cell

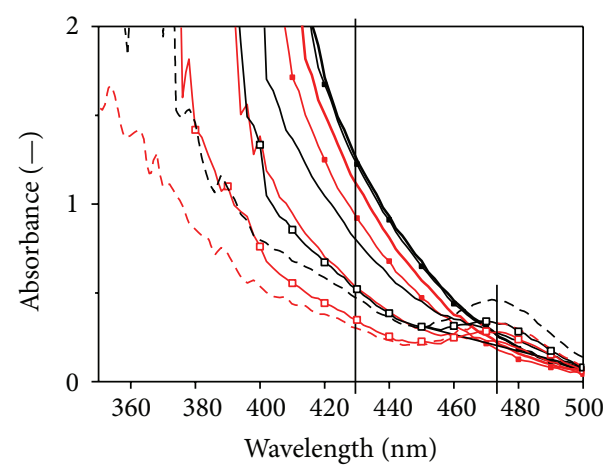

$\begin{array}{ll}- \text { Reference } 5 \mathrm{wt} \% \mathrm{H}_{2} \mathrm{O} & - \text { Day } 35,10 \mathrm{wt} \% \mathrm{H}_{2} \mathrm{O} \\ - \text { Reference } 10 \mathrm{wt} \% \mathrm{H}_{2} \mathrm{O} & -- \text { Day } 71,5 \mathrm{wt} \% \mathrm{H}_{2} \mathrm{O} \\ \rightarrow \text { Day } 5,5 \mathrm{wt} \% \mathrm{H}_{2} \mathrm{O} & \longrightarrow \text { Day } 71,10 \mathrm{wt} \% \mathrm{H}_{2} \mathrm{O} \\ - \text { Day } 5,10 \mathrm{wt} \% \mathrm{H}_{2} \mathrm{O} & -- \text { Day } 99,5 \mathrm{wt} \% \mathrm{H}_{2} \mathrm{O} \\ - \text { Day } 35,5 \mathrm{wt} \% \mathrm{H}_{2} \mathrm{O} & -- \text { Day } 99,10 \mathrm{wt} \% \mathrm{H}_{2} \mathrm{O}\end{array}$

(c) GF2

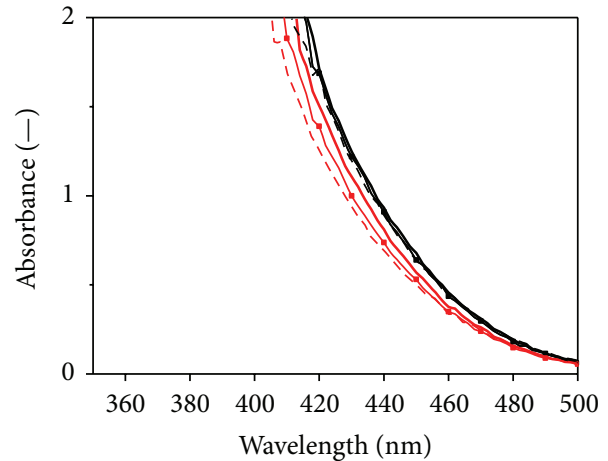

$\begin{array}{ll}- \text { Reference } 5 \mathrm{wt} \% \mathrm{H}_{2} \mathrm{O} & \rightarrow \text { Day } 5,10 \mathrm{wt} \% \mathrm{H}_{2} \mathrm{O} \\ - \text { Reference } 10 \mathrm{wt} \% \mathrm{H}_{2} \mathrm{O} & --- \text { Day } 99,5 \mathrm{wt} \% \mathrm{H}_{2} \mathrm{O} \\ - \text { Day } 5,5 \mathrm{wt} \% \mathrm{H}_{2} \mathrm{O} & -- \text { - Day } 99,10 \mathrm{wt} \% \mathrm{H}_{2} \mathrm{O}\end{array}$

(b) GF1

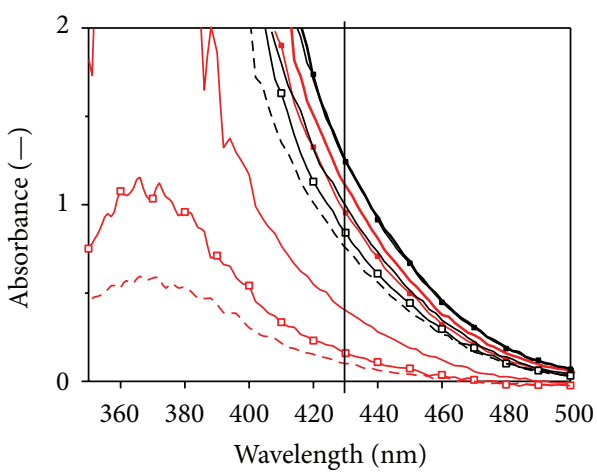

$\begin{array}{ll}- \text { Reference } 5 \mathrm{wt} \% \mathrm{H}_{2} \mathrm{O} & - \text { Day } 35,10 \mathrm{wt} \% \mathrm{H}_{2} \mathrm{O} \\ - \text { Reference } 10 \mathrm{wt} \% \mathrm{H}_{2} \mathrm{O} & - \text { Day } 71,5 \mathrm{wt} \% \mathrm{H}_{2} \mathrm{O} \\ \rightarrow \text { Day } 5,5 \mathrm{wt} \% \mathrm{H}_{2} \mathrm{O} & - \text { - Day } 71,10 \mathrm{wt} \% \mathrm{H}_{2} \mathrm{O} \\ \rightarrow \text { Day } 5,10 \mathrm{wt} \% \mathrm{H}_{2} \mathrm{O} & -- \text { Day } 99,5 \mathrm{wt} \% \mathrm{H}_{2} \mathrm{O} \\ - \text { Day 35, } 5 \mathrm{wt} \% \mathrm{H}_{2} \mathrm{O} & -- \text { Day } 99,10 \mathrm{wt} \% \mathrm{H}_{2} \mathrm{O}\end{array}$

(d) GF3
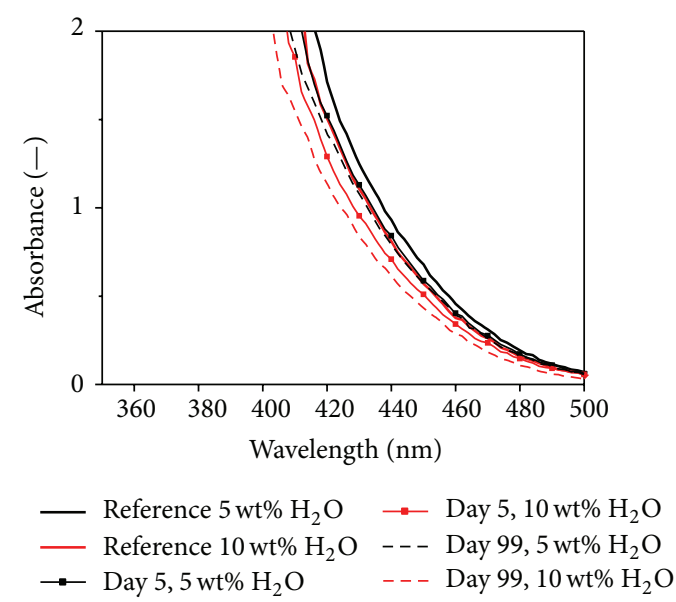

(e) GF4

FIGURE 4: Development of absorbance spectra during ageing of the reference cell (no GF) and the test cells with 5 and 10 wt\% $\mathrm{H}_{2} \mathrm{O}$ added to the redox electrolyte. (a) Reference cell with no GF; no change in absorbance over time, (b) test cell with GF1 showing stable absorbance spectra over time, (c) test cell with GF2; notice the appearance of a new peak at $475 \mathrm{~nm}$ and the decrease in absorbance at lower wavelengths, (d) test cell with GF3 showing continuous decrease in absorbance over time, and (e) test cell with GF4 which is relatively stable over time. 


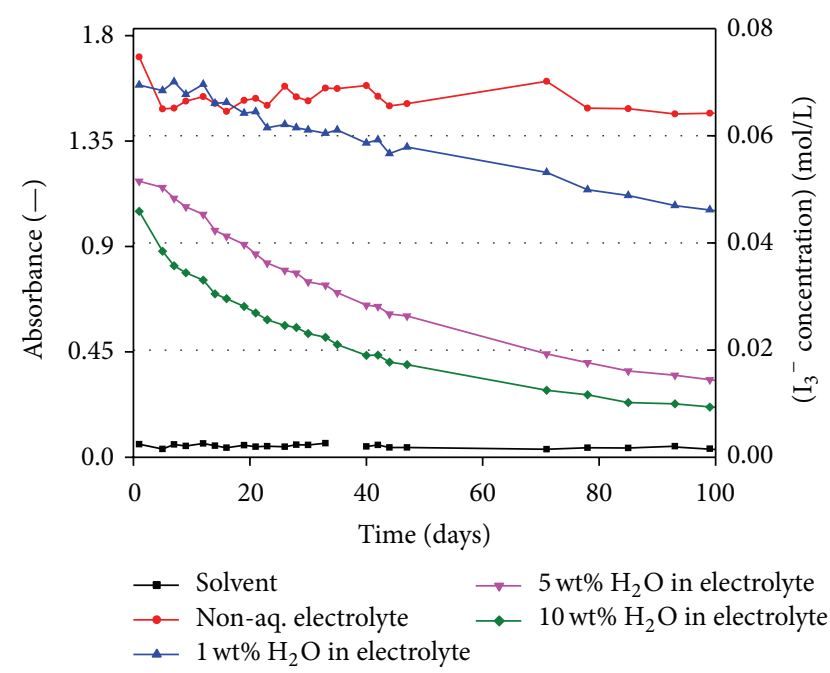

(a) GF2

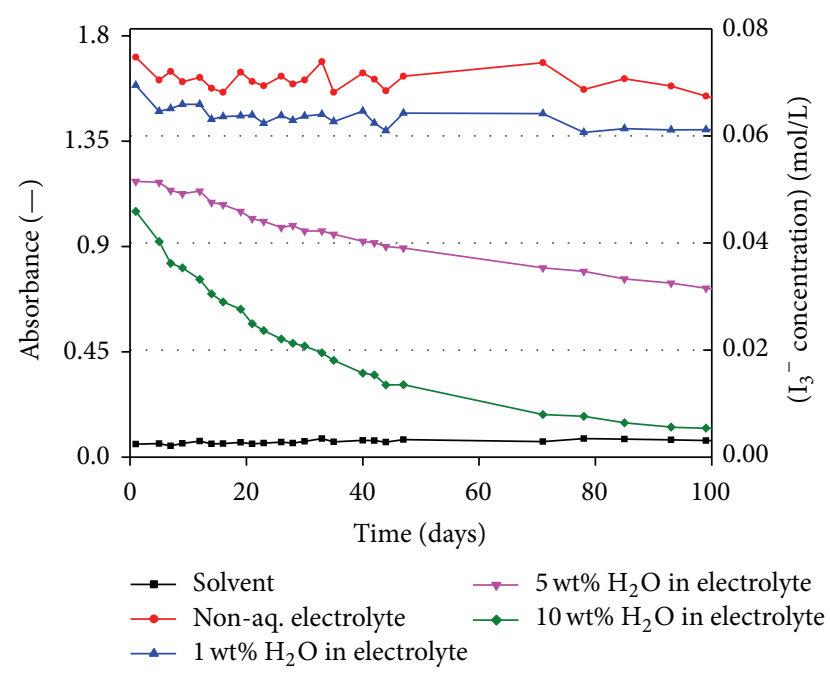

(b) GF3

FIGURE 5: Absorbance at $430 \mathrm{~nm}$ as a function of time for the test cells filled with solvent, nonaqueous redox electrolyte, and redox electrolyte with 1, 5, and $10 \mathrm{wt} \% \mathrm{H}_{2} \mathrm{O}$. (a) Test cell with GF2. Absorbance decreases over time for cells with 1, 5, and 10 wt $\% \mathrm{H}_{2} \mathrm{O}$ in electrolyte. (b) Test cell with GF3. Absorbance decreases over time for cells with 5 and $10 \mathrm{wt} \% \mathrm{H}_{2} \mathrm{O}$ in electrolyte.

\section{Discussion}

For DSC cells and modules, the $\mathrm{I}_{3}{ }^{-}$concentration is one of the possible current-limiting parameters. Therefore, significant $\mathrm{I}_{3}{ }^{-}$depletion will lead to a decrease in electrical performance [13].

4.1. Test Cell with GF2. The absorbance measurements revealed a significant decrease in $\mathrm{I}_{3}{ }^{-}$absorbance over time for the samples in contact with GF2 and aqueous redox electrolyte.

The EDX analysis of leached elements from GF2 revealed a precipitate of bismuth and iodine. Even though the absorbance measurements showed decaying absorbance at $430 \mathrm{~nm}$ over time (Figure 5(a)), the cells did not visually bleach, which can be explained by the occurrence of a new absorbance peak at $475 \mathrm{~nm}$ as seen in Figure 4(c). This peak could be assigned to the $\mathrm{BiI}_{4}{ }^{-}$formation in aqueous redox electrolyte, as the absorbance peak of $\mathrm{BiI}_{4}{ }^{-}$is reported at $460 \mathrm{~nm}$ in acetonitrile [19].

4.2. Test Cell with GF3. The GF3 test cells with 5 and $10 \mathrm{wt} \% \mathrm{H}_{2} \mathrm{O}$-containing redox electrolyte showed significant decrease in $\mathrm{I}_{3}{ }^{-}$absorbance over time as seen in Figure 5(b). The electrolyte bleached due to $\mathrm{I}_{3}{ }^{-}$depletion.

EDX revealed that zinc was leached from the GF in aqueous redox electrolyte and formed a thermally stable compound with iodine. At present, the formed zinc-iodine complex is not known, but could be present in the form of $\mathrm{Zn}\left(\mathrm{I}_{3}\right)_{2}(\mathrm{aq}),\left[\mathrm{ZnI}_{3}\right]^{-}(\mathrm{aq})$, or $\left[\mathrm{ZnI}_{3}\left(\mathrm{H}_{2} \mathrm{O}\right)\right]^{-}$(aq) [20]. The formed complex did not change the absorbance spectrum in the range of $350-500 \mathrm{~nm}$ over time. Despite the missing determination of the formed compound, the experimental results (Section 3.2) clearly showed a continuous decrease in
$\mathrm{I}_{3}{ }^{-}$absorbance over time. This will be detrimental for the DSC operation.

4.3. Influence of GF Composition on Stability. Glass dissolves by two mechanisms: selective leaching of glass modifier elements or complete glass dissolution [21]. It is known that soda-lime glass dissolves in $\mathrm{H}_{2} \mathrm{O}$ with a dissolution rate in the order of $10^{-6} \mathrm{~cm}^{2} / \mathrm{s}$ [21]. The process is controlled by the exchange of $\mathrm{Na}^{+}$ions with $\mathrm{H}^{+}$, which breaks up the glass matrix [22].

GF2 and GF3 became unstable when $\mathrm{H}_{2} \mathrm{O}$ was added to the redox electrolyte. GF2 exhibited a low melting temperature compared with GF1, which consists of same major elements. Evidently the solubility of GF2 is higher than GF1. This can be the result of a low bond strength so it is easier to break up the glass structure. The effect of $\mathrm{H}_{2} \mathrm{O}$ in electrolyte led to leaching of bismuth ions that reacted with iodide and formed the $\mathrm{BiI}_{4}{ }^{-}$complex, as detected by spectrophotometry.

The composition of GF3 has a high content of $\mathrm{ZnO}$ compared with $\mathrm{SiO}_{2}$ and $\mathrm{Al}_{2} \mathrm{O}_{3}$. As $\mathrm{SiO}_{2}$ and $\mathrm{Al}_{2} \mathrm{O}_{3}$ have a strong tendency to form a tetrahedral structure which forms the glass matrix, $\mathrm{ZnO}$ will act as a glass modifier by obtaining interstitial positions in the glass structure. Zinc ions can then readily be exchanged with $\mathrm{H}^{+}$if present in the electrolyte, which leads to leaching of zinc ions [23].

GF3 contained the same major oxides as GF4, but GF4 had a higher melting temperature, which explains the higher chemical stability towards $\mathrm{H}_{2} \mathrm{O}$.

4.4. Accelerated Tests. In order to test different kinds of GFs, an accelerated test would be preferred. Based on the experiences with the experiment carried out, reflections are made towards applicability and design of accelerated testing. 


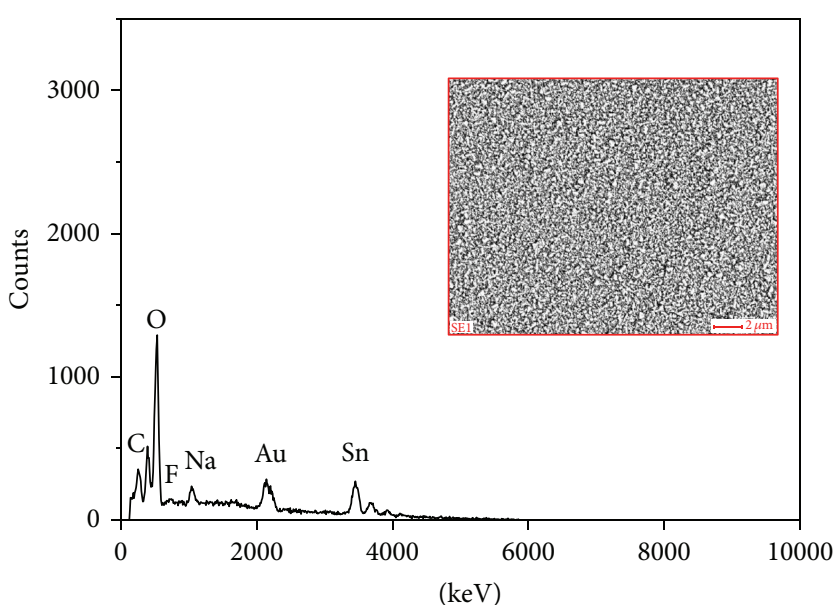

_ Non-aq. electrolyte

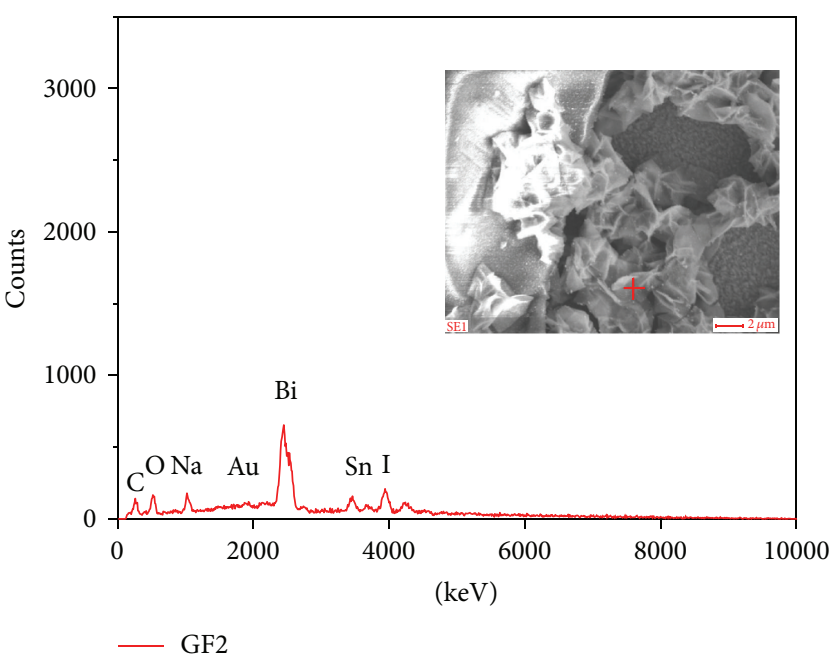

(b)

(a)

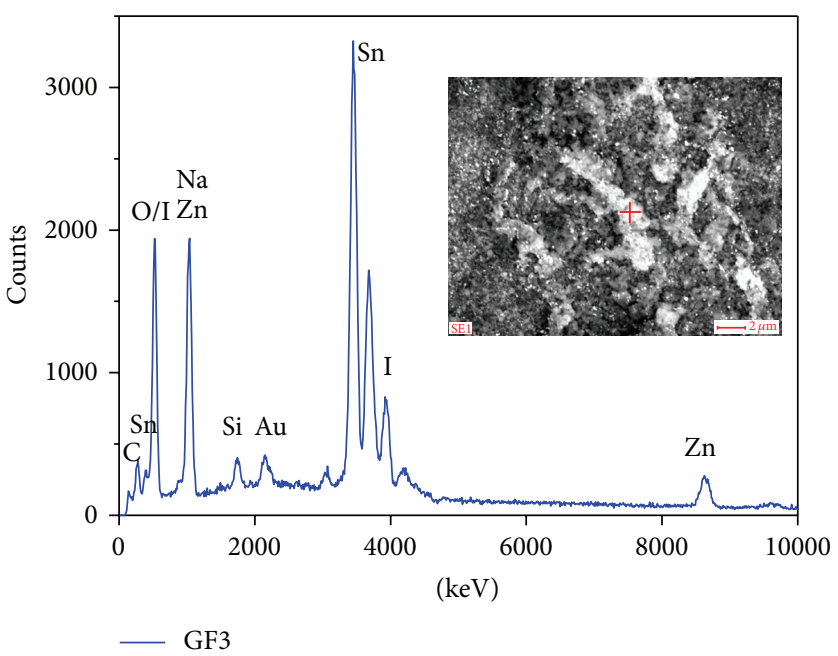

(c)

FIGURE 6: EDX spectra of precipitates on TCO after evaporation of electrolyte. Samples were sputtered with Au to increase conductivity. (a) Area analysis as indicated from the SEM inset of nonaqueous electrolyte precipitate. Sn, O, and F originate from the TCO substrate. C and Na are trace amounts from the electrolyte. (b) Spot analysis of precipitate from cell with $10 \mathrm{wt} \% \mathrm{H}_{2} \mathrm{O}$-containing electrolyte in contact with GF2. $\mathrm{Bi}$ and I are detected due to GF2 and electrolyte interaction. (c) Spot analysis of precipitate from cell with $10 \mathrm{wt} \% \mathrm{H}_{2} \mathrm{O}$-containing electrolyte in contact with GF3. Zn and I are detected due to GF3 and electrolyte interaction. Si is detected due to increased acceleration voltage, so the soda-lime glass was reached by the electron beam.

The ageing conditions of the samples were mild as the samples were stored at room temperature and in the dark. Interaction between GF and redox electrolyte with $\mathrm{H}_{2} \mathrm{O}$ could be accelerated by using a cell design where diffusionlimitation of $\mathrm{I}_{3}^{-}$is negligible. Furthermore, the storage temperature could be increased, but this would require a different hole- and cell sealing material than the present Surlyn.

In a GF-sealed DSC, the GF exposed to electrolyte is only present at the sealing edges compared with the investigated cells with an openly exposed GF layer. The GF area in these cells is approximately 30 times larger than in the case of a cell with a plate distance of $25 \mu \mathrm{m}$ sealed with GF, so the ratio between GF area and electrolyte volume is significantly larger, accelerating a possible reaction between the cell components.

\section{Conclusions}

In this work, interaction of glass frit (GF) with $\mathrm{I}^{-} / \mathrm{I}_{3}{ }^{-}$electrolyte and $\mathrm{H}_{2} \mathrm{O}$ present in the electrolyte was investigated for four different GFs. Thin cells with a confined layer of GF were fabricated to enable in situ monitoring of the $\mathrm{I}_{3}{ }^{-}$absorbance change of the redox electrolyte. The change in $\mathrm{I}_{3}^{-}$absorbance was assigned to a reaction between the GF and the electrolyte and was used to evaluate the chemical stability of the different GFs.

All GFs were stable in nonaqueous redox electrolyte. When $\mathrm{H}_{2} \mathrm{O}$ was added to the electrolyte, two of the investigated GFs became unstable. GF2 based on $\mathrm{SiO}_{2}-\mathrm{B}_{2} \mathrm{O}_{3}-\mathrm{Bi}_{2} \mathrm{O}_{3}$ leached bismuth, and a bismuth iodide complex was formed. This was confirmed by the new absorbance peak assigned to $\mathrm{BiI}_{4}{ }^{-}$and the detection of bismuth in the electrolyte by EDX. 
GF3, based on $\mathrm{ZnO}-\mathrm{SiO}_{2}-\mathrm{Al}_{2} \mathrm{O}_{3}$, became unstable when 5 and $10 \mathrm{wt} \% \mathrm{H}_{2} \mathrm{O}$ were added to the redox electrolyte. The instability was due to the high $\mathrm{ZnO}$ content, where the addition of $\mathrm{H}_{2} \mathrm{O}$ in electrolyte caused zinc ion leaching. The leached zinc ions reacted with $\mathrm{I}_{3}{ }^{-}$and caused gradual $\mathrm{I}_{3}{ }^{-}$depletion. EDX analysis on the extracted electrolyte confirmed the formation of a compound containing zinc and iodine.

To maintain long-term electrical performance and stability of the dye-sensitized solar cell, a nonreactive and watertight sealing is needed. The methodology of the study can be used to test various GF candidates in a system comparable with the working DSC.

\section{Conflict of Interests}

The authors declare that they have no conflict of interests.

\section{Acknowledgments}

This work is supported by Seoul Metropolitan Government in the Joint Project KU/Fraunhofer-ISE Next Generation Solar Cell Research Center (KFnSC) between Konkuk University, Republic of Korea, and Fraunhofer ISE, Germany ( Seoul R\&BD Program no. WR090671). The authors would like to thank Jutta Zielonka, Fraunhofer ISE, for the SEM and EDX analysis.

\section{References}

[1] B. O’Regan and M. Grätzel, "A low-cost, high-efficiency solar cell based on dye-sensitized colloidal $\mathrm{TiO}_{2}$ films," Nature, vol. 353, no. 6346, pp. 737-740, 1991.

[2] A. Hinsch, W. Veurman, H. Brandt, R. A. Loayza, K. Bialecka, and K. F. Jensen, "Worldwide first fully up-scaled fabrication of $60 \times 100 \mathrm{~cm}^{2}$ dye solar module prototypes," Progress in Photovoltaics, vol. 20, no. 6, pp. 698-710, 2012.

[3] R. Sastrawan, "Photovoltaic modules of dye solar cells," Dissertation, University Freiburg Freiburg, Germany, 2006 http:// www.freidok.uni-freiburg.de/volltexte/2623/pdf/Sastrawan_ Photovoltaic_modules_of_dye_solar_cells_Dissertation.pdf.

[4] B. Macht, M. Turrión, A. Barkschat, P. Salvador, K. Ellmer, and $\mathrm{H}$. Tributsch, "Patterns of efficiency and degradation in dye sensitization solar cells measured with imaging techniques," Solar Energy Materials and Solar Cells, vol. 73, no. 2, pp. 163-173, 2002.

[5] Y.-S. Jung, B. Yoo, M. K. Lim, S. Y. Lee, and K.-J. Kim, "Effect of Triton X-100 in water-added electrolytes on the performance of dye-sensitized solar cells," Electrochimica Acta, vol. 54, no. 26, pp. 6286-6291, 2009.

[6] A. Hagfeldt, G. Boschloo, L. Sun, L. Kloo, and H. Pettersson, "Dye-sensitized solar cells," Chemical Reviews, vol. 110, no. 11, pp. 6595-6663, 2010.

[7] A. Hinsch, J. M. Kroon, R. Kern et al., "Long-term stability of dye-sensitised solar cells," Progress in Photovoltaics, vol. 9, no. 6, pp. 425-438, 2001.

[8] A. Hinsch, S. Behrens, M. Berginc et al., "Material development for dye solar modules: results from an integrated approach," Progress in Photovoltaics, vol. 16, no. 6, pp. 489-501, 2008.
[9] H. Chen, S. Wang, H. Lin, G. Wang, S. Wang, and G. Yang, "Stability of dye sensitized solar cells with glass frit sealant," Key Engineering Materials, vol. 512-515, pp. 1619-1624, 2012.

[10] R. Sastrawan, J. Beier, U. Belledin et al., "A glass frit-sealed dye solar cell module with integrated series connections," Solar Energy Materials and Solar Cells, vol. 90, no. 11, pp. 1680-1691, 2006.

[11] W. J. Lee, E. Ramasamy, D. Y. Lee, and J. S. Song, "Glass frit overcoated silver grid lines for nano-crystalline dye sensitized solar cells," Journal of Photochemistry and Photobiology A, vol. 183, no. 1-2, pp. 133-137, 2006.

[12] T. Kitamura, K. Okada, H. Matsui, and N. Tanabe, "Durability of dye-sensitized solar cells and modules," Journal of Solar Energy Engineering, vol. 132, no. 2, pp. 0211051-0211057, 2010.

[13] A. Hauch and A. Georg, "Diffusion in the electrolyte and charge-transfer reaction at the platinum electrode in dyesensitized solar cells," Electrochimica Acta, vol. 46, no. 22, pp. 3457-3466, 2001.

[14] P. Gerhardinger and D. Strickler, "Fluorine doped tin oxide coatings: over 50 years and going strong," Key Engineering Materials, vol. 380, pp. 169-178, 2008.

[15] Z. Kebede and S.-E. Lindquist, "Donor-acceptor interaction between non-aqueous solvents and $\mathrm{I}_{2}$ to generate $\mathrm{I}_{3}^{-}$, and its implication in dye sensitized solar cells," Solar Energy Materials and Solar Cells, vol. 57, no. 3, pp. 259-275, 1999.

[16] K. A. Fletcher, S. Pandey, I. K. Storey, A. E. Hendricks, and S. Pandey, "Selective fluorescence quenching of polycyclic aromatic hydrocarbons by nitromethane within room temperature ionic liquid 1-butyl-3-methylimidazolium hexafluorophosphate," Analytica Chimica Acta, vol. 453, no. 1, pp. 89-96, 2002.

[17] J. D. J. Ingle and S. R. Crouch, Spectrochemical Analysis, Prentice Hall, New Jersey, NJ, USA, 1988.

[18] I. Lee, S. Hwang, and H. Kim, "Reaction between oxide sealant and liquid electrolyte in dye-sensitized solar cells," Solar Energy Materials and Solar Cells, vol. 95, no. 1, pp. 315-317, 2011.

[19] O. Horváth and I. Mikó, "Spectra, equilibrium and photoredox chemistry of iodobismuthate(III) complexes in acetonitrile," Inorganica Chimica Acta, vol. 304, no. 2, pp. 210-218, 2000.

[20] H. Wakita, G. Johansson, M. Sandström, P. L. Goggin, and H. Ohtaki, "Structure determination of zinc iodide complexes formed in aqueous solution," Journal of Solution Chemistry, vol. 20, no. 7, pp. 643-668, 1991.

[21] D. E. Clark and B. K. Zoitos, Corrosion of Glass, Ceramics and Ceramic Superconductors: Principles, Testing, Characterization and Applications, William Andrew, New Jersey, NJ, USA, 1993.

[22] R. H. Do Remus, Y. Mehrotra, W. A. Lanford, and C. Burman, "Reaction of water with glass: influence of a transformed surface layer," Journal of Materials Science, vol. 18, no. 2, pp. 612-622, 1983.

[23] A. A. Khedr and H. A. ElBatal, "Corrosion of zinc-containing cabal glasses by various leaching solutions," Journal of the American Ceramic Society, vol. 79, no. 3, pp. 733-741, 1996. 

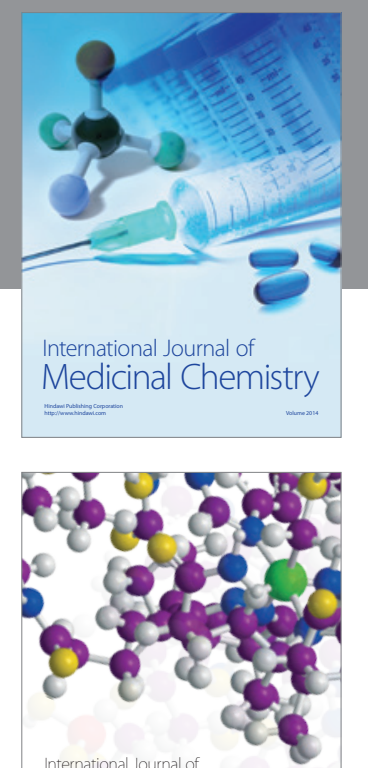

\section{Carbohydrate} Chemistry

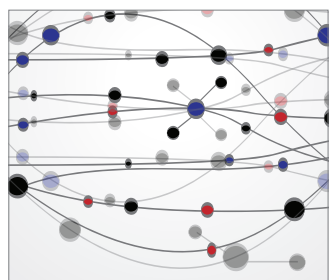

The Scientific World Journal
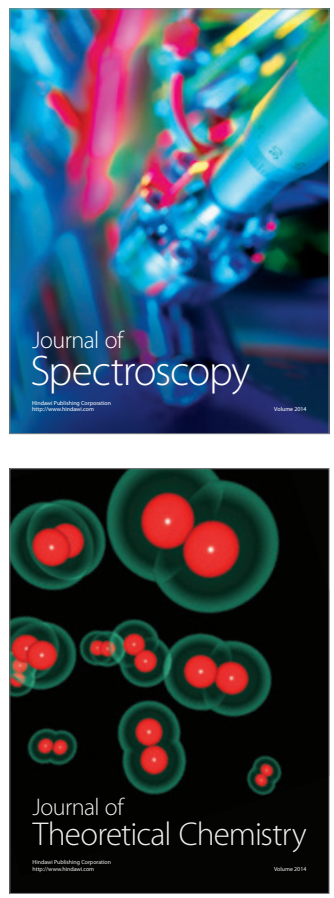
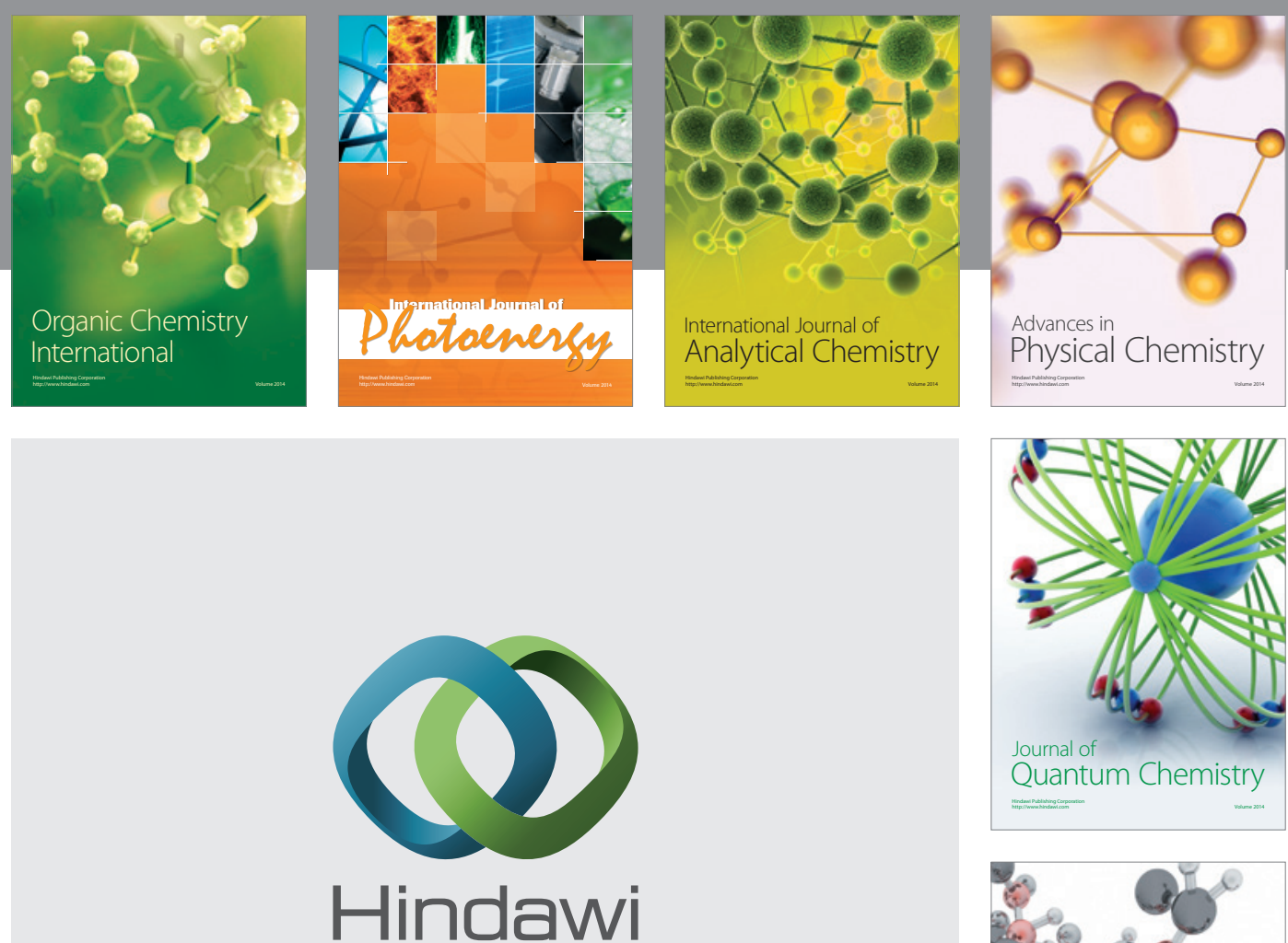

Submit your manuscripts at

http://www.hindawi.com

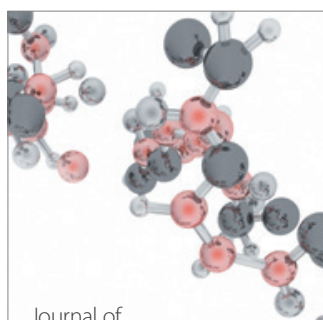

Analytical Methods

in Chemistry

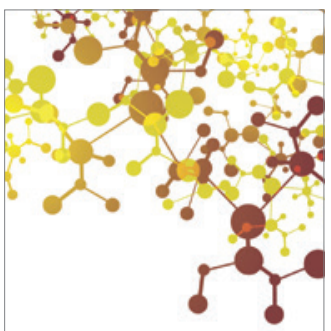

Journal of

Applied Chemistry

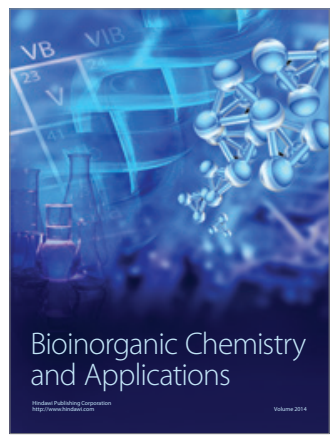

Inorganic Chemistry
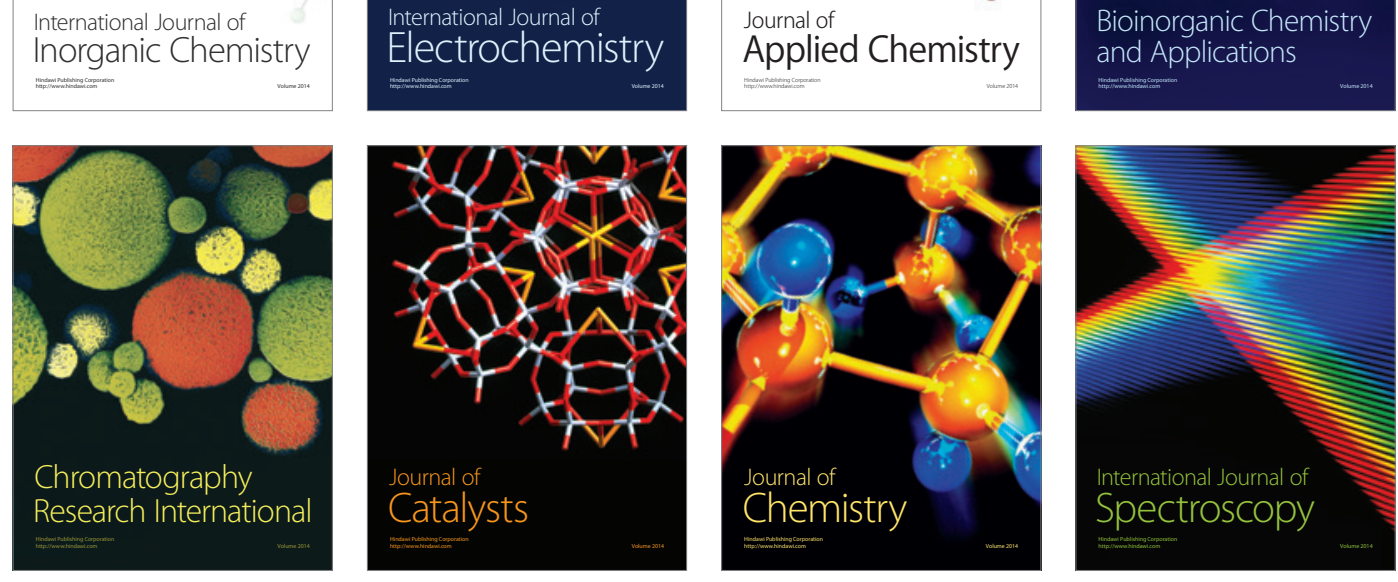